DOE/ORP01-1460\&D1

\title{
Removal Action Report on the Waste Evaporator Facility, Building 3506, at Oak Ridge National Laboratory, Oak Ridge, Tennessee
}

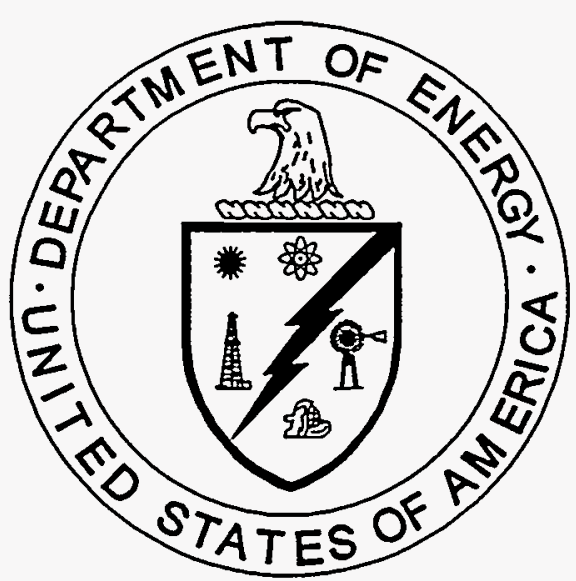

AECENED APR 281997 OSTI

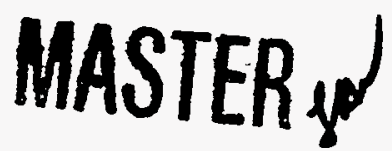

OASTRIBUTION OF THIS DOCUMENT IS UNLLMITED

This document has been approved by the ORNL Technical Information Office, for release to the public. Date: $7 / 17 / 96$ 
This report has been reproduced directly from the best available copy.

Available to DOE and DOE contractors from the Office of Scientific and Technical Information, P.O. Box 62, Oak Ridge, TN 37831; prices available from 423-576-8401 (fax 423-576-2865).

Available to the public from the National Technical Information Service, U.S. Department of Commerce, 5285 Port Royal Rd., Springfield, VA 22161. 


\section{DISCLAIMER}

This report was prepared as an account of work sponsored by an agency of the United States Government. Neither the United States Government nor any agency thereof, nor any of their employees, makes any warranty, express or implied, or assumes any legal liability or responsibility for the accuracy, completeness, or usefulness of any information, apparatus, product, or process disclosed, or represents that its use would not infringe privately owned rights. Reference herein to any specilic commercial product, process, or service by trade name, trademark, manufacturer, or otherwise does not necessarily constitute or imply its endorsement, recommendation, or favoring by the United States Government or any agency thereof. The views and opinions of authors expressed herein do not necessarily state or reflect those of the United States Government or any agency thereof. 


\section{DISCLAIMER}

Portions of this document may be illegible electronic image products. Images are produced from the best available original document. 
DOE/OR/01-1460\&D1

Energy Systems Environmental Restoration Program

Removal Action Report on the Waste Evaporator Facility, Building 3506, at Oak Ridge National Laboratory, Oak Ridge, Tennessee

Date Issued—July 1996

Prepared for the U.S. Department of Energy Office of Environmental Management under budget and reporting code EW 20

Environmental Management Activities at the OAK RIDGE NATIONAL LABORATORY

Oak Ridge, Tennessee 37831-8169 managed by

LOCKHEED MARTIN ENERGY SYSTEMS, INC.

for the U.S. DEPARTMENT OF ENERGY under contract DE-AC05-84OR21400 


\section{PREFACE}

This Removal Action Report on the Waste Evaporator Facility, Building 3506, at Oak Ridge National Laboratory, Oak Ridge, Tennessee was prepared in accordance with requirements under the Comprehensive Environmental Response, Compensation, and Liability Act (CERCLA) for reporting construction actions for public review. This work was performed under Work Breakdown Structure (WBS) 1.4.12.6.2.01.12.06, Activity Data Sheet 3701, "ORNL Decontamination and Decommissioning." Publication of this document meets a Federal Facility Agreement (FFA) milestone date of December 30, 1996. This document provides the Environmental Restoration Program with information regarding the construction activities related to a non-time critical removal action. It compares the work performed with that which was proposed in the Action Memorandum for Building 3506 Waste Evaporator Facility Removal Action at the Oak Ridge National Laboratory, Oak Ridge, Tennessee (Jacobs 1995b) and provides technical justification for deviations from the proposed plan. 



\section{CONTENTS}

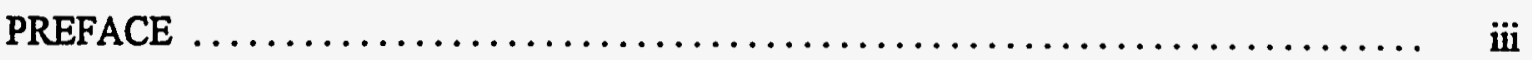

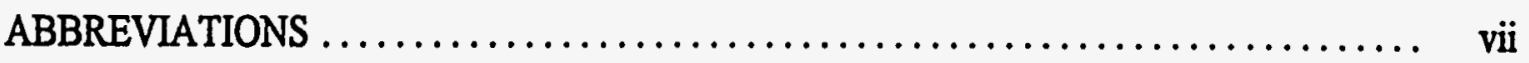

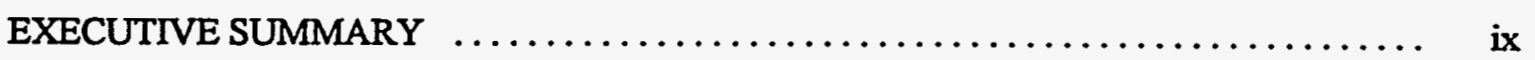

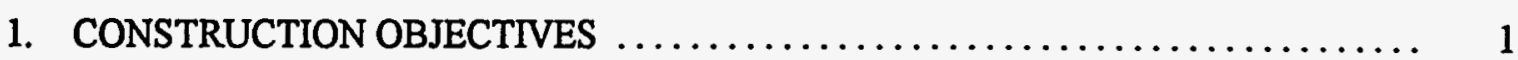

1.1 REMOVE ACCUMULATED WATER FROM CELL $\ldots \ldots \ldots \ldots \ldots \ldots \ldots, 1$

1.2 REMOVE CONTAMINATED SEDIMENT FROM CELL ............... 1

1.3 REMOVE CONTAMINATED SOIL FROM GALLERY CRAWLSPACE ...... 1

1.4 DISMANTLE THE STRUCTURE TO ONE FOOT BELOW-GRADE ......... 1

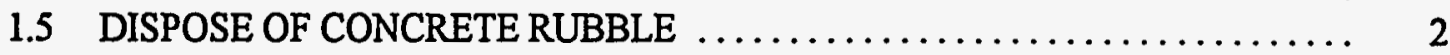

1.6 COVER REMAINING BELOW-GRADE MATERIALS .............. 2

2. APPLICABLE OR RELEVANT AND APPROPRIATE REQUIREMENTS $\ldots \ldots \ldots, 2$

2.1 ALTERATION/DESTRUCTION OF ARCHAEOLOGIC RESOURCES ...... 3

2.2 RADIATION PROTECTION $\ldots \ldots \ldots \ldots \ldots \ldots \ldots \ldots \ldots \ldots \ldots \ldots \ldots \ldots \ldots, 3$

2.3 FUGITIVE EMISSIONS $\ldots \ldots \ldots \ldots \ldots \ldots \ldots \ldots \ldots \ldots \ldots \ldots \ldots \ldots \ldots, 3$

2.4 SURFACE WATER RUNOFF $\ldots \ldots \ldots \ldots \ldots \ldots \ldots \ldots \ldots \ldots \ldots \ldots \ldots \ldots \ldots, \quad 3$

2.5 EXCAVATION OF SOIL/SEDIMENT $\ldots \ldots \ldots \ldots \ldots \ldots \ldots \ldots \ldots \ldots \ldots, 3$

2.6 REMOVAL OF ASBESTOS $\ldots \ldots \ldots \ldots \ldots \ldots \ldots \ldots \ldots \ldots \ldots \ldots \ldots \ldots \ldots, 3$

2.7 STORAGE OF EXCAVATED SOIL $\ldots \ldots \ldots \ldots \ldots \ldots \ldots \ldots \ldots \ldots \ldots \ldots, 3$

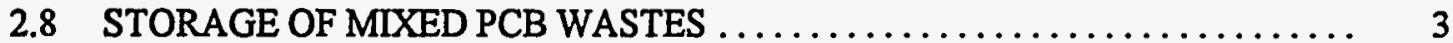

2.9 DISPOSAL OF LOW LEVEL WASTE $\ldots \ldots \ldots \ldots \ldots \ldots \ldots \ldots \ldots \ldots, 3$

2.10 DISPOSAL OF EXCAVATED SOIL $\ldots \ldots \ldots \ldots \ldots \ldots \ldots \ldots \ldots \ldots, 4$

2.11 DISPOSAL OF MTXED PCB WASTES $\ldots \ldots \ldots \ldots \ldots \ldots \ldots \ldots \ldots \ldots, 4$

2.12 DISPOSAL OF NONHAZARDOUS WASTE $\ldots \ldots \ldots \ldots \ldots \ldots \ldots \ldots, 4$

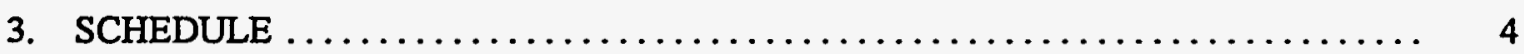

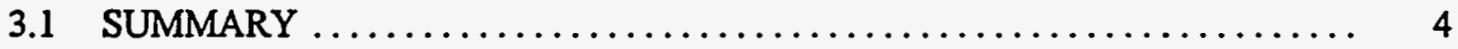

3.2 DISCUSSION OF SCHEDULE VARIANCES $\ldots \ldots \ldots \ldots \ldots \ldots \ldots \ldots \ldots, 4$

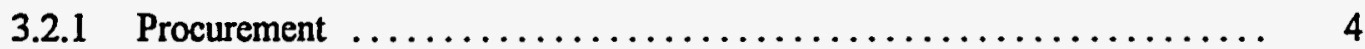

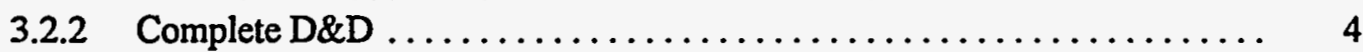

3.2.3 Removal Action Report $\ldots \ldots \ldots \ldots \ldots \ldots \ldots \ldots \ldots \ldots \ldots \ldots, 4$

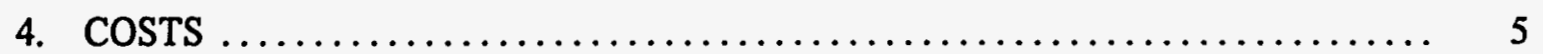

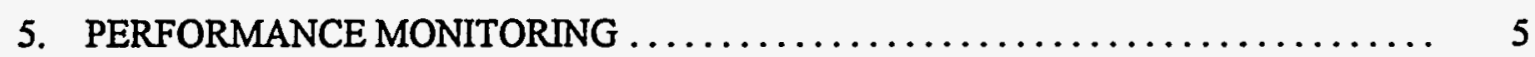

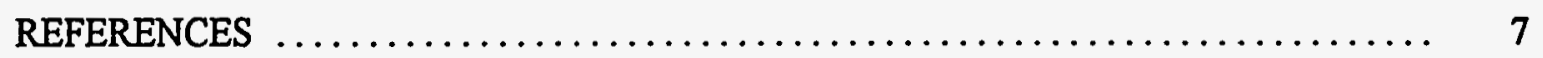

Appendix. CONSTRUCTION PHOTOGRAPHS $\ldots \ldots \ldots \ldots \ldots \ldots \ldots \ldots \ldots \ldots$ A-1 
. $\quad \therefore$ 


\section{ABBREVIATIONS}

ARARs

CERCLA

$D \& D$

DOE

FFA

LLW

ORNL

PCB

WBS

WEF applicable or relevant and appropriate requirements

Comprehensive Environmental Response, Compensation, and Liability Act decontamination and decommissioning

Department of Energy

Federal Facility Agreement

low level waste

Oak Ridge National Laboratory

polychlorinated biphenyl

Work Breakdown Structure

Waste Evaporator Facility 


\section{EXECUTIVE SUMMARY}

The construction phase of the Waste Evaporator Facility (WEF) Removal Action was completed on June 25, 1996. The construction objectives set forth in the Action Memorandum (Jacobs 1995b) were met. There were a few deviations from the proposed plan that reduced activity durations and waste volumes generated. The Action Memorandum does not require follow-on monitoring. 


\section{CONSTRUCTION OBJECTIVES}

The objective of the Waste Evaporator Facility (WEF) Removal Action was to remove the access obstacle to the Oak Ridge National Laboratory (ORNL) South Tank Farm presented by the above-grade portions of the WEF. The Engineering Evaluation/Cost Analysis Document (DOE/OR/02-1353\&D2) (Jacobs 1995a) recommended dismantlement of the above-grade portion of the facility as the chosen corrective action.

The following sections provide a summary of the detailed construction objectives as stated in the Department of Energy (DOE)-approved, Action Memorandum for Building 3506 Waste Evaporator Facility Removal Action at the Oak Ridge National Laboratory, Oak Ridge, Tennessee, (DOE/OR/02-1381\&D2) (Jacobs 1995b).

\subsection{REMOVE ACCUMULATED WATER FROM CELL}

The accumulated rainwater in the cell was sampled, analyzed, and removed in accordance with the approved sampling and analysis plan and the project waste management plan. The water was transferred to the ORNL Liquid Waste Operations Process Waste Treatment System.

\subsection{REMOVE CONTAMINATED SEDIMENT FROM CELL}

The sediment residing on the bottom of the cell floor was sampled, analyzed, and removed in accordance with the approved sampling and analysis plan, and the project waste management plan. The sediment was drummed as mixed polychlorinated biphenyl (PCB) waste and sent to the K-25 Site for eventual disposition.

\subsection{REMOVE CONTAMINATED SOIL FROM GALLERY CRAWLSPACE}

Approximately six to ten inches of soil was removed from the floor of the gallery crawlspace, down to the level of the footer, and transferred to a B-25 box for pick up by Energy Systems Waste Management in accordance with the approved project waste management plan. The soil was determined to be radiologically contaminated and sample analysis confirmed the presence of mercury slightly above regulatory limits. The box of soil was sent to the K-25 sight for eventual disposition. In the process of checking the crawlspace for depth to refusal, the subcontractor discovered a concrete-encased, fifteen-inch diameter, tile storm drain running beneath the gallery crawlspace. This forced a minor change in plans for placing concrete rubble into the crawlspace as discussed in Sect. 1.5 below.

\subsection{DISMANTLE THE STRUCTURE TO ONE FOOT BELOW-GRADE}

All extemal, non-concrete structures were first removed, decontaminated where necessary, and packaged in accordance with the approved project waste management plan. More asbestos-containing materials and contaminated scrap steel were generated than originally planned, but this could not be avoided because the original plans were based upon incomplete site characterization. After these removal activities, only a concrete 
shell remained. The concrete structure was then segmented into blocks down to one foot below-grade using a diamond-wire saw. The blocks were sized to fit neatly into the remaining below-grade portions of both the cell and gallery crawlspace. During the course of this project, grade level was further defined as the top of the concrete pad which surrounded the facility. Concrete cutting was completed in approximately 50 days which was much longer than the original estimate of 20 days.

\subsection{DISPOSE OF CONCRETE RUBBLE}

As discussed in Sect. 1.4 above, the sawn concrete blocks which were radiologically surveyed and determined to be less than Category II were placed in the below-grade portions of the cell and gallery crawlspace areas. Per ORNL procedure, Category II material is not to exceed $5 \mathrm{mrad} / \mathrm{h}$ beta/gamma and $6000 \mathrm{dpm} / 100 \mathrm{~cm}^{2}$. The primary radioisotopes of concern were Cs-137 and Sr-90.

Wall sections known to be contaminated in excess of Category II levels were marked to be disposed of as low level waste (LLW). Large blocks were placed first, with small pieces placed toward the end to fill void spaces. When stacking concrete blocks in the cell area, it was noted that the level of the blocks were two to four inches above the one foot below-grade line. This situation was mitigated by maintaining the required amount of clean fill over the entire facility area. On the gallery side of the structure, the concrete gallery floor was lowered intact onto the earthen floor of the crawlspace. This provided a shield for the storm drain running beneath the crawlspace. Concrete left over when all below-grade voids were filled was surveyed and disposed of as free-releasable construction debris or LLW, depending upon contamination levels. The concrete which was not free-releasable was subsequently turned over to the Gunite and Associated Tanks remediation project for their future use.

\subsection{COVER REMAINING BELOW-GRADE MATERIALS}

When the below-grade structure was completely filled, remaining small voids were filled with clean construction earth fill. A geotextile fabric was then placed over the entire remaining structure and a six-inch layer of sand was placed over this in accordance with the approved plans and specifications. Finally, a geomembrane was placed over the sand layer, and one foot of clean compacted fill was placed over this. At the request of the Gunite and Associated Tanks Treatability Study project team, the enclosure was left in place for their future use, so the area was covered with gravel, not seeded with grass as originally planned.

\section{APPLICABLE OR RELEVANT AND APPROPRIATE REQUIREMENTS}

The following sections present a summary of the Applicable or Relevant and Appropriate Requirements (ARARs) described in the Action Memorandum (Jacobs 1995b), along with the specific actions taken in the field during decontamination and decommissioning (D\&D) activities. 


\subsection{ALTERATION/DESTRUCTION OF ARCHAEOLOGIC RESOURCES}

The State Historic Preservation was contacted and concurrence with actions was documented.

\subsection{RADIATION PROTECTION}

Lockheed Martin and subcontractor radiation protection technicians were on-site at all times while work was being performed. In addition, the sub-contractor's project management were well versed in DOE Order 5400.5 and its requirements.

\subsection{FUGITIVE EMISSIONS}

Allied Technology Group's approved work plan included dust and emissions control provisions. For example, a large enclosere was erected completely covering the work area, and water was used to wet the surfaces being cut with the diamond-wire saw.

\subsection{SURFACE WATER RUNOFF}

Best management practices were implemented to avoid surface water runoff due to project activities.

\subsection{EXCAVATION OF SOIL AND SEDIMENT REMOVAL}

The project sampling and analysis plan included soil and sediments scheduled for removal. Once analysis results were received, the soil and sediment were handled in accordance with the approved project waste management plan.

\subsection{REMOVAL OF ASBESTOS}

The project work plan addressed asbestos-containing materials scheduled for removal. The asbestoscontaining materials were handled in accordance with the approved project waste management plan.

\subsection{STORAGE OF EXCAVATED SOIL}

The soil was stored in accordance with the approved project waste management plan.

\subsection{STORAGE OF MIXED PCB WASTES}

The mixed PCB wastes were stored in accordance with the approved project waste management plan.

\subsection{DISPOSAL OF LOW LEVEL WASTE}

Disposal of LLW was performed in accordance with the approved project waste management plan. 


\subsection{DISPOSAL OF EXCAVATED SOIL}

Excavated soil is being stored at the K-25 Site for eventual treatment /disposal in accordance with the approved project waste management plan.

\subsection{DISPOSAL OF MIXED PCB WASTES}

The mixed PCB waste is being stored at the K-25 Site for eventual treatment/disposal in accordance with the approved project waste management plan.

\subsection{DISPOSAL OF NONHAZARDOUS WASTE}

Disposal of nonhazardous waste was performed in accordance with the approved project waste management plan.

\section{SCHEDULE}

\subsection{SUMMARY}

A summary of the schedule outlined in the Action Memorandum (Jacobs 1995b) and of the actual completion dates is shown below.

$\begin{array}{lll}\text { Activity } & \text { Proposed Completion Date } & \text { Actual Completion Date } \\ \text { D\&D Design } & \text { July } 1995 & \text { July } 1995 \\ \text { Procurement } & \text { September } 1995 & \text { November } 1995 \\ \text { Complete D\&D } & \text { February 1996 } & \text { June } 1996 \\ \text { Removal Action Report } & \text { April 1996 } & \text { July } 1996\end{array}$

\subsection{DISCUSSION OF SCHEDULE VARIANCES}

\subsubsection{Procurement}

Incentive Task Order negotiations required approximately two months longer than originally planned. This delay impacted all subsequent activities.

\subsubsection{Complete D\&D}

Field work was delayed due to procurement delays discussed above.

\subsubsection{Removal Action Report}

The report could not be completed until D\&D was complete. Therefore, the report was delayed due to procurement delays discussed above. 


\section{COSTS}

The WEF Action Memorandum estimated total D\&D costs at \$IM (Jacobs 1995b). Actual D\&D costs were approximately $\$ 1.1 \mathrm{M}$.

\section{PERFORMANCE MONITORING}

The approved Action Memorandum (Jacobs 1995b) does not require follow-on performance monitoring. 
_.....

- 


\section{REFERENCES}

Jacobs (Jacobs Engineering Group, Inc.). 1995a. Engineering Evaluation/Cost Analysis for Building 3506 Waste Evaporator Facility at the Oak Ridge National Laboratory, Oak Ridge, Tennessee, DOE/OR/02-1353\&D2. Prepared for the U. S. Deparments of Energy, Oak Ridge, Tennessee. May.

Jacobs (Jacobs Engineering Group, Inc.). 1995b. Action Memorandum forBuilding 3506

Waste Evaporator Facility Removal Action at the Oak Ridge National Laboratory, Oak Ridge, Tennessee, DOE/OR/02-1381\&D2. Prepared for the U. S. Department of Energy, Oak Ridge, Tennessee. July. 
$\ldots \ldots$ 
Appendix

CONSTRUCTION PHOTOGRAPHS 
$\ldots \ldots$ 


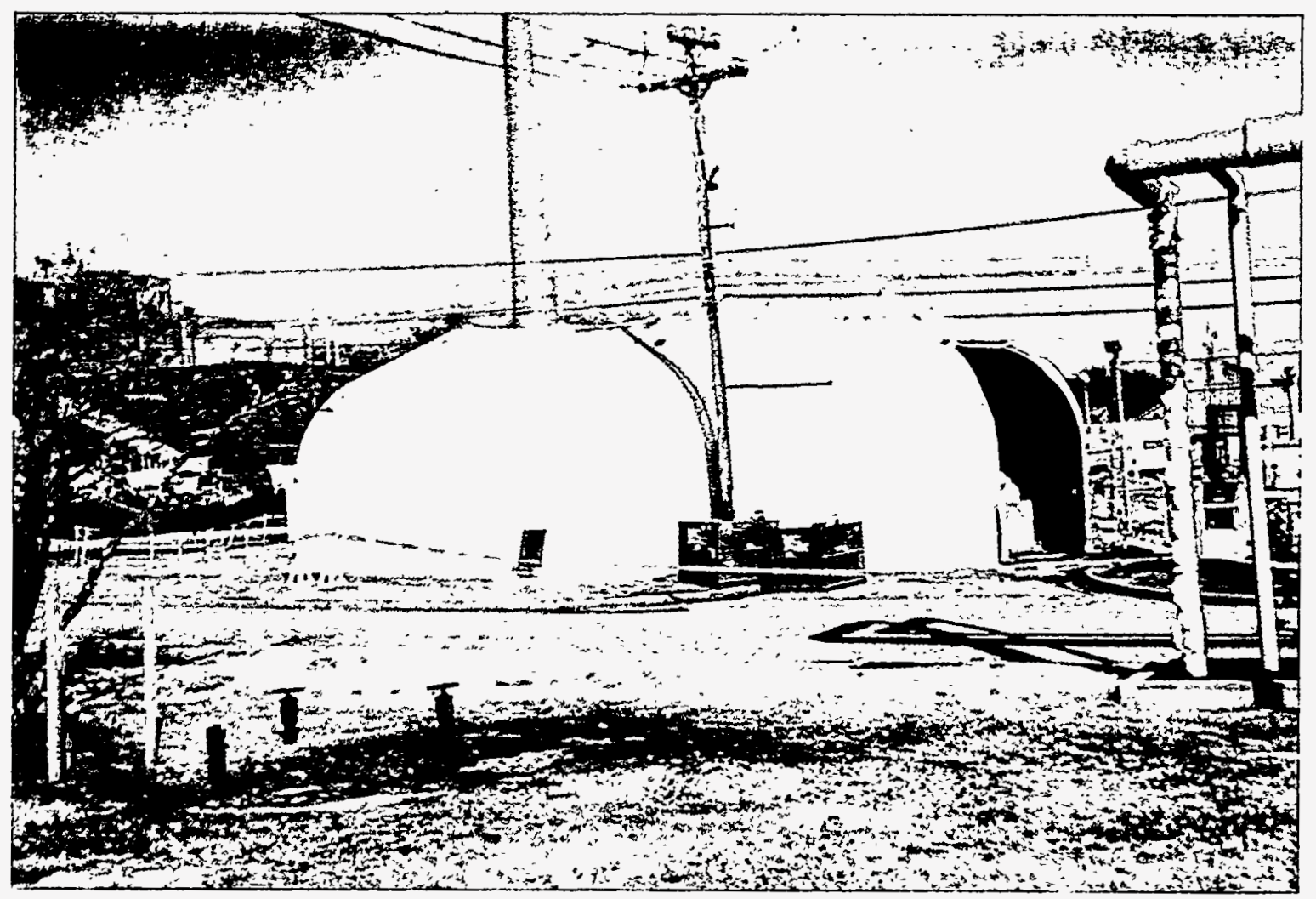

Fig. 1. Protective enclosure that was erected over the Waste Evaporator Facility site.

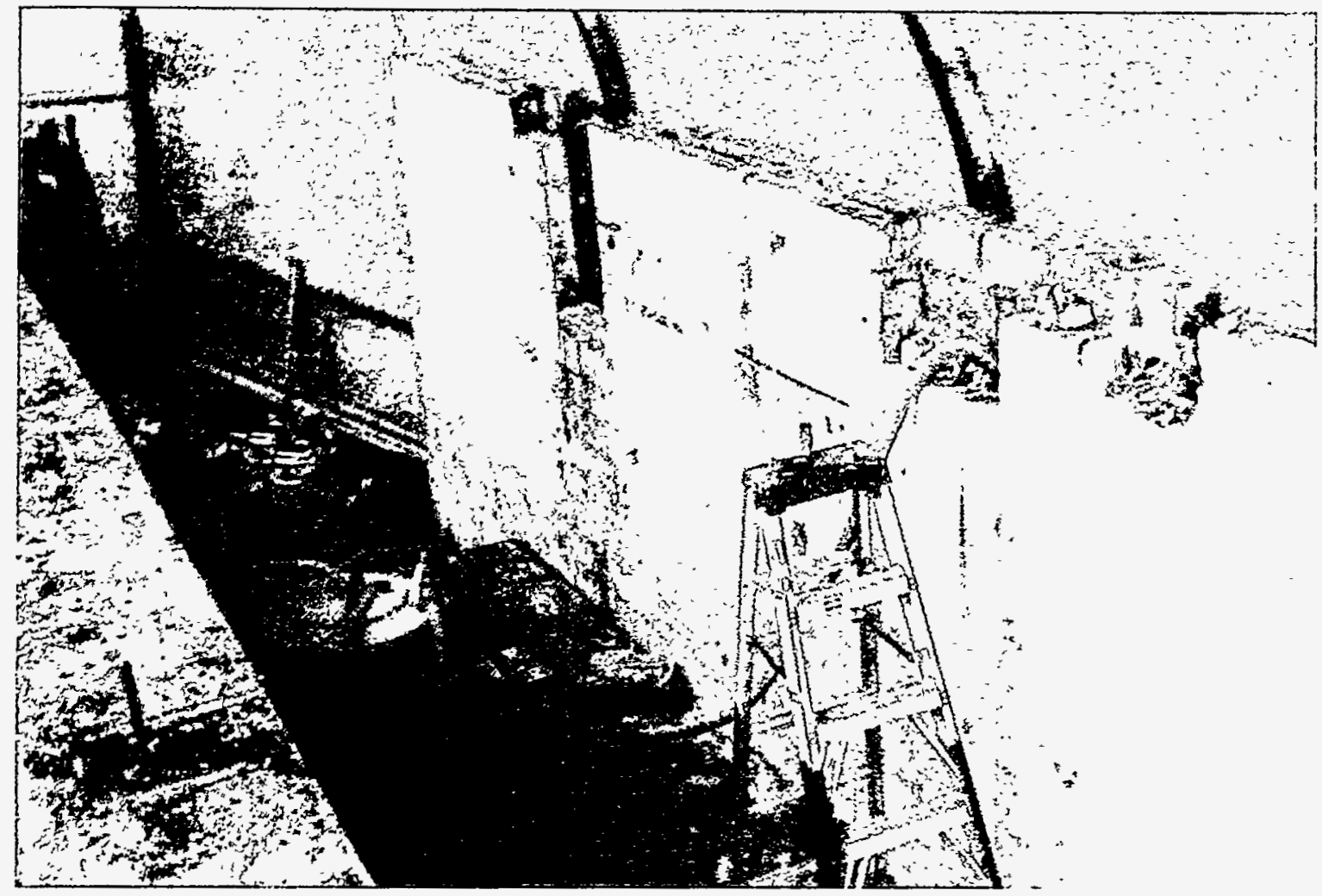

Fig. 2. Demolition of the WEF gallery in progress. 


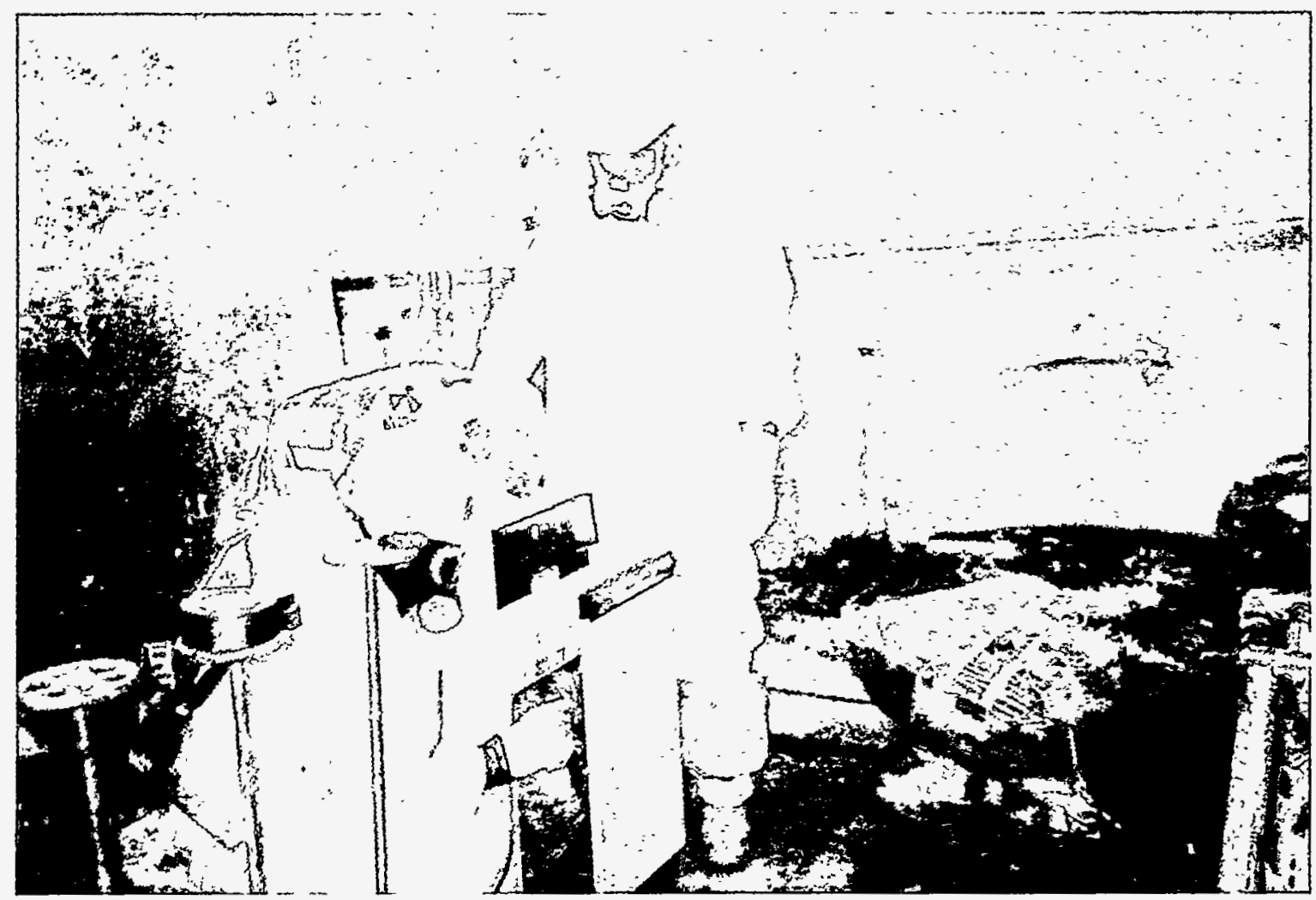

Fig. 3. Standard trash compactor being used on compactible radioactive waste.

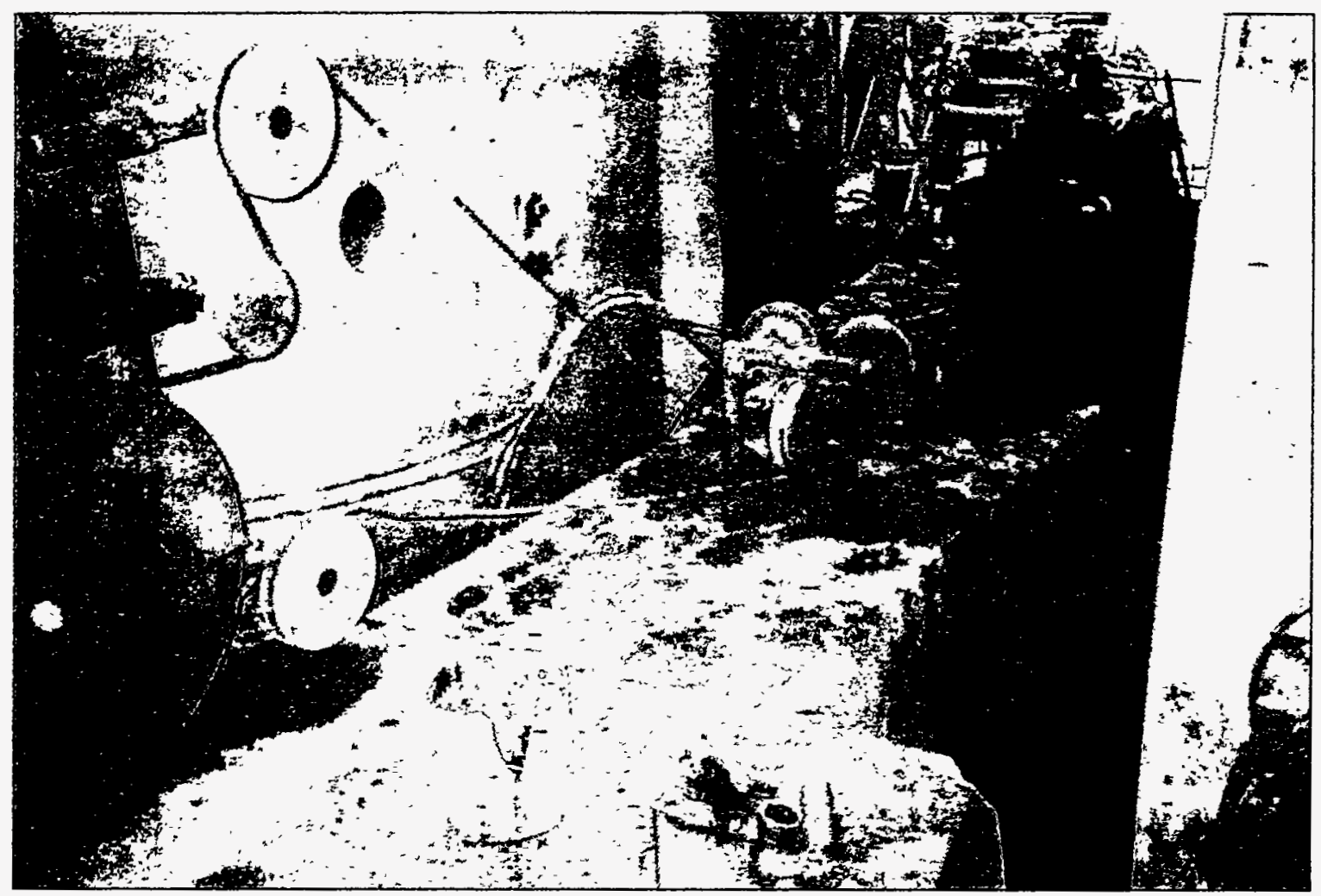

Fig. 4. Diamond-wire saw being used to section the concrete cell walls. 


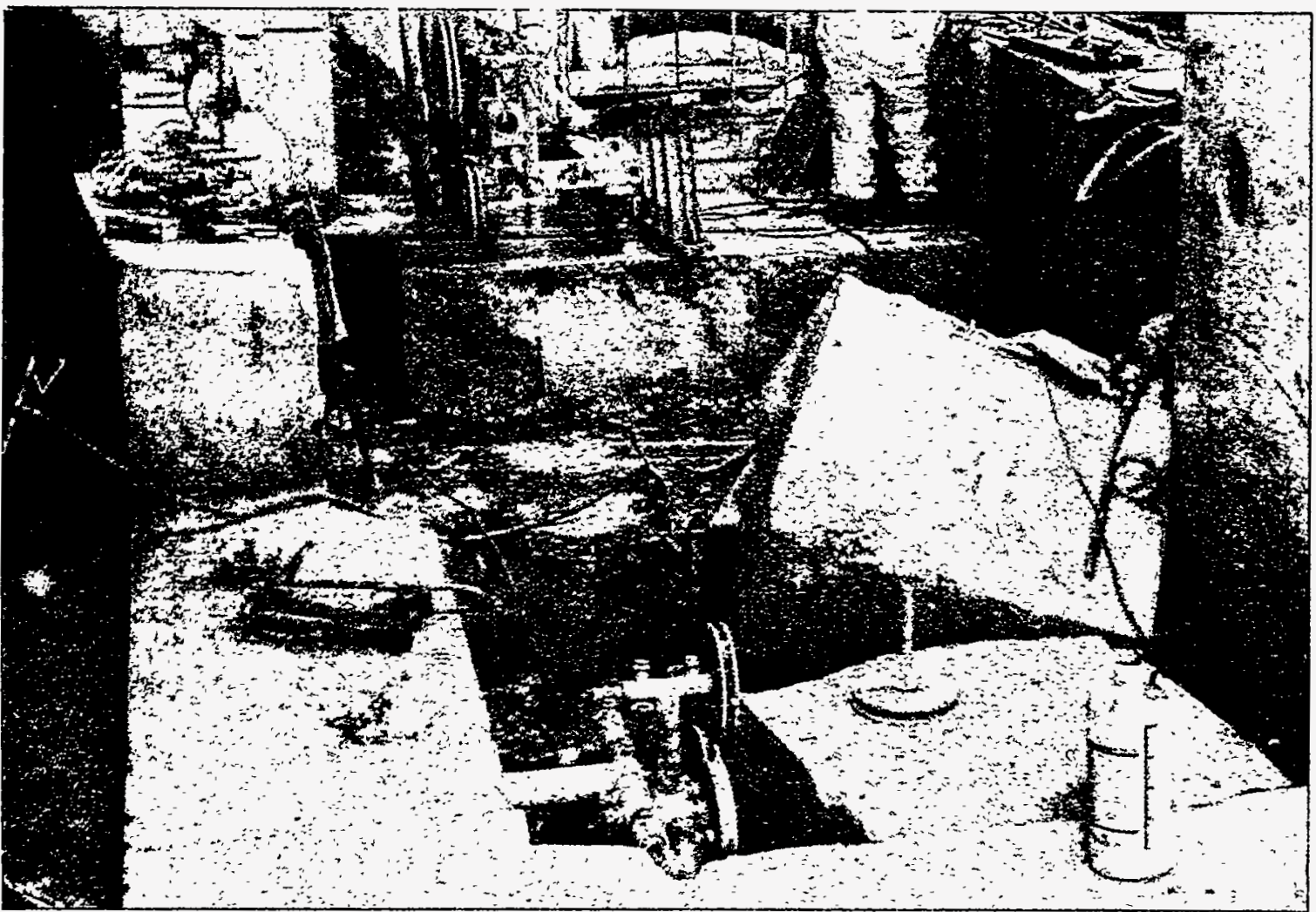

Fig. 5. Sectioning the concrete walls and placing them in the below-grade area.

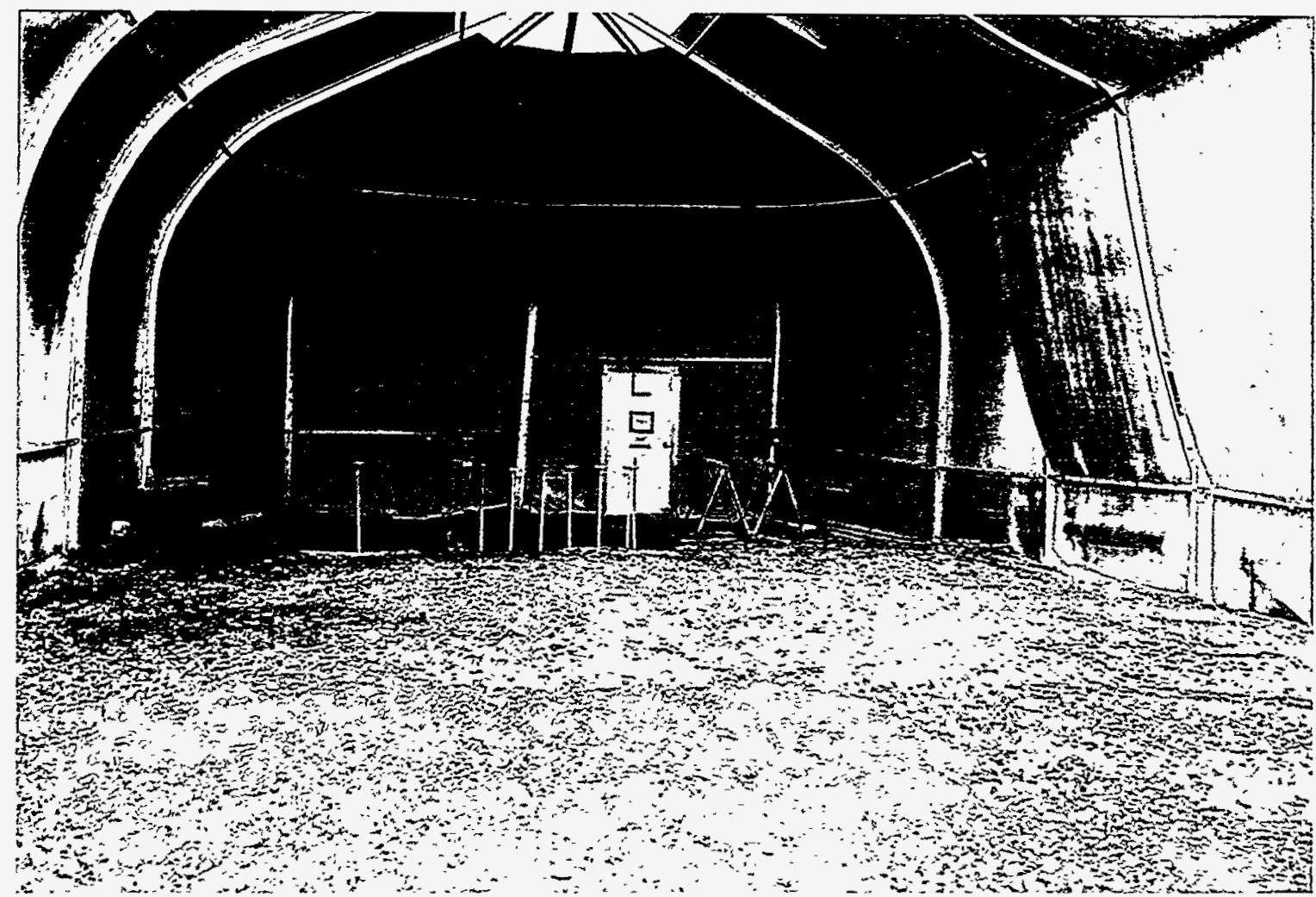

Fig. 6. View of the site upon completion of D\&D activities. 
$\ldots \ldots \ldots+\ldots$ 


\section{DISTRIBUTION}

1. L. V. Asplund

2. H. L. Boston

3. W. D. Brickeen

4. T. W. Burwinkle

5. S. E. Childs

6. C. Clark, Jr.

7. R. L. Collins

8. D. G. Cope

9. B. E. Copeland

10. B. W. Henderson

11-13. G. J. Mandry

14-16. D. M. Matteo

17. P. T. Owen

18. W. E. Palmer

19. A. S. Quist

20. A. D. Reynolds

21. P. R. Sanders

22. P. A. Schrandt

23. M. M. Slater

24. I. M. Smith

25. M. G. White

26. Central Research Library

27. ER Document Management Center-RC

28. Office of Assistant Manager for Energy Research and Development, DOE Oak Ridge Operations Office, P.O. Box 2001, Oak Ridge TN 37831-8600

29. R. L. Nace, Team Leader, Fernald/Ohio Team, Office of Environmental Restoration, U.S. Department of Energy, Cloverleaf Building, EM-425, 19901 Germantown Road, Germantown, MD 20874

30. J. W. Wagoner II, Team Leader, Portsmouth/Paducah/Weldon Spring Team, Office of Environmental Restoration, U.S. Department of Energy, Cloverleaf Building, EM-424, 19901 Germantown Road, Germantown, MD 20874

31-32. R. C. Sleeman, Director, Environmental Restoration Division, DOE Oak Ridge Operations Office, P.O. Box 2001, Oak Ridge, TN 37831-8541

33-34. Allied Technology Group, 99A Midway Lane, Oak Ridge, TN 37830

35-36. Office of Scientific and Technical Information, P.O. Box 62, Oak Ridge, TN 37831 